\title{
Changes in flavor ingredients of distilled fruit brandy according to the aging container and maturation period
}

\author{
Sangmi Jung ${ }^{\ddagger}$, Minhee Kwon ${ }^{\ddagger}$, Bonghwan Chung, Moonjin Ra* \\ Hongcheon Institute of Medicinal Herb, 101 Yeonbongri, Hongcheon 25142, Korea
}

\section{과실 브랜디의 숙성용기 및 숙성기간에 따른 휘발성 향기성분 분석}

\author{
정상미 ${ }^{\ddagger}$ · 권민희 ${ }^{\ddagger}$ 정봉환 · 라문진* \\ 재단법인 홍천메디칼허브연구소
}

\begin{abstract}
We investigated the effects of container type (oak, glass, and stainless vessels), maturation period, and application of two different fruit materials (Actinidia arguta (ChungSan, Korean name), and Vitis coignetiae (Black Sun, Korean name) cultivated in Gangwon, Korea) on the flavor characteristics of brandies. After 17 months of aging, significant changes in the flavor ingredients occurred only in the brandies matured in oak containers. Particularly, the level of isoamyl alcohol, an important flavor component, increased, indicating $1,294.3 \mathrm{mg} / \mathrm{L}$ and 4,125.4 mg/L in Actinidia arguta brandy respectively, and $898.3 \mathrm{mg} / \mathrm{L}$ and $1,605.6 \mathrm{mg} / \mathrm{L}$ in Vitis coignetiae brandy respectively. In contrast, the levels of acetaldehyde and methanol, which are volatile components decreased significantly after seven months of aging. In addition, changes in the brandy flavor based on the maturation period were confirmed by measuring the proportion of fatty acid ethyl esters. In general, the proportion of fatty acid ethyl esters increased as the maturation period decreased. Therefore, we found that the brandy matured in oak containers for all maturation periods was the most preferable based on the sensory evaluation, which might be correlated with a balance between the desirable and undesirable components with aging.
\end{abstract}

Key words : storage container, distilled liquor, maturation, volatile compounds, fusel oils

서 론

증류주로 분류되는 브랜디 제품은 특정 과실을 원료로 첨 가하여 발효시킨 발효주를 증류하여 얻은 증류액을 오크통에 넣어 장기간 숙성시킨 코냑으로 많이 알려져 있다. 증류가 끝 난 원액은 오크통에서 숙성과정을 거치며, 원액은 추출, 숙 성, 산화 크게 세가지 화학적 변화를 거치며, 브랜디의 품질 에 가장 중요한 요소인 향기과 미각에 영향을 미친다. 첫째, 추출과정은 오크통으로부터 탄닌, 리그닌 등의 성분이 원액
안에 녹아 호박색을 띄며, 둘째, 숙성과정으로 오크통 성분과 원액 중의 산, 당분, 알코올 그리고 페놀성분들이 반응하여 부케라고 불리는 특유의 향기와 맛을 만들게 된다(Park, 1995). 마지막으로 산화과정에서 지방산에스테르화, 퓨젤유 향미성분의 농축 등에 의하여 향미와 맛이 증가하게 된다. 따 라서 브랜디의 품질은 숙성용기의 재질에 따라서 많은 영향 을 미치게 된다. 국내 증류주의 경우, 저장용기에 따른 특성 연구로는 전통 쌀 증류식 소주의 숙성연구(Kang 등, 2017), 입국으로 제조한 증류주의 숙성에 따른 품질연구(Lee 등,

*Corresponding author. E-mail : leeramoonjin@gmail.com, Phone : +82-33-439-3247, Fax : +82-33-439-3239

${ }^{\ddagger}$ These authors contributed equally to this work.

Received 18 September 2020; Revised 20 November 2020; Accepted 14 December 2020.

Copyright (c) The Korean Society of Food Preservation.

This is an Open Access article distributed under the terms of the Creative Commons Attribution Non-Commercial License (http://creativecommons.org/licenses/by-nc/4.0) which permits unrestricted non-commercial use, distribution, and reproduction in any medium, provided the original work is properly cited. 
2014) 및 누룩 사용 발효주의 숙성용기에 따른 특성연구(Lee 등, 2014) 등이 있지만, 과실 증류주의 숙성용기에 따른 특성 연구는 미비한 실정이다.

증류주의 고유한 풍미를 결정하는 요인으로는 숙성용기 이외에 숙성기간에 따른 향미성분의 생성과 축적에 기인한 다. 일반적으로 증류주의 숙성 중의 변화를 3 단계로 나누어 보면 초기 숙성은 아세트알데하이드(acetaldehyde) 등의 가 스향 성분을 제거시켜 자극적인 향을 감소시키며, 중기 숙성 은 증류주의 카르보닐화합물(carbonyl compound)의 중축합 반응(polymerization)이 일어나고, 3 년 이상 장기숙성 시에는 지방산의 에스테르(fatty acid ester) 생성, 퓨젤유(fusel oil) 향미 성분의 농축, 물과 알코올의 화합에 의한 맛의 조화가 증가되는 것으로 알려져 있다(Lee 등, 2001). 증류주에는 인 체에 해로운 영향을 미치는 아세트알데하이드, 메탄올 등의 유해물질과 지방산 에스테르 및 퓨젤유 등의 향기성분이 포함 되어 있다고 알려져 있다. 주류의 향기성분은 제조 중 발효과 정보다 숙성과정에서 생성되는데 주성분은 에틸알코올이지 만, 알코올류, 에스테르류, 알데하이드류, 유기산류, 페놀류 등 많은 성분으로 구성된다(Chun 등, 2012). 브랜디 특유의 향기 를 결정하는 주요한 인자 중에 하나인 퓨젤유에는 n-프로판올 (n-propanol), 이소부탄올(isobutanol), n-부탄올(n-butanol), 이 소아밀알코올(isoamyl alcohol), n-아밀알코올(n-amyl alcohol) 을 함유한다. 이러한 퓨젤유는 탈아미노, 탈탄산작용을 거쳐 생성되며, 원료 중의 아미노산 함유량, 사용균주, 증류조건 등 여러 조건에 따라 변화될 수 있어 주류의 품질관리 지표로 활 용될 수 있다(Chung, 2012; Lee, 1989; Lee, 1994; Lee, 2011).

강원도농업기술원에서 지역특화작목으로 머루와 다래를 집중육성하여 그 성과로 주류용으로 적합한 품종인 머루(블 랙썬)와 다래(그린볼)를 품종 등록하였다. 본 연구에서는 머 루와 다래를 활용하여 증류주(브랜디)를 개발하는데 있어, 숙 성용기 및 숙성기간에 따른 휘발성 향기성분 및 퓨젤유의 함 량 변화와 지방산 및 지방산 에스테르류의 함량변화를 분석 하여 머루와 다래 브랜디의 품질 변화 특성을 비교할 수 있는 기초자료를 제공하고자 하였다.

\section{재료 및 방법}

\section{실험재료}

본 증류주 제조에 사용된 머루와 다래는 강원도농업기술 원 자체육성품종으로 강원도 내 농가에 보급되어진 원료를 구매하여 사용하였다. 발효에 사용된 효모는 상업용 효모 (Fermivin, DSM Food Specialties B.V. Netherlands)를 사용 하였다.

\section{시약}

연구에서 사용된 시약인 n-propanol(Junsei Chemical Co., Ltd., Tokyo, Japan), isobutanol(Kanto Chemical Co., Inc., Tokyo, Japan), $n$-butanol(Daejung Chemical Co., Ltd.), isoamyl alcohol (Daejung Chemical Co., Ltd.), $n$-amyl alcohol(Kanto Chemical Co., Inc.), acetate aldehyde(Kanto Chemical Co., Inc.), ethyl acetate(Daejung Chemical Co., Ltd.), methyl alcohol(TEDIA, Fairfield, OH, USA)은 GC 분석용 특급시약 으로 구입해 분석에 사용하였다.

\section{표준용액의 조제}

분석에 사용된 표준용액은 각각의 표준물질 약 $0.1 \mathrm{~mL}$ 를 $1,000 \mathrm{~mL}$ 메스플라스크에 넣고 $40 \%$ 에탄올 수용액으로 표선 을 맞추고 지용성 PTFE syringe filter $(25 \mathrm{~mm}, 0.45 \mu \mathrm{m})$ 로 여 과 후 표준용액으로 사용하였다. 표준용액을 $40 \%$ 에탄올 수 용액으로 적절히 희석하여 검량선용 표준용액을 조제하였다.

\section{증류주 제조}

증류주 제조를 위한 과실증류주는 과실(머루, 다래)을 착 즙량이 $50-60 \%(\mathrm{w} / \mathrm{w})$ 가 되도록 압착하여 착즙한 후 과즙의 당도가 $22{ }^{\circ} \mathrm{Brix}$ 가 되도록 가당한 후 과즙의 $0.02 \%(\mathrm{w} / \mathrm{w})$ 효 모를 접종하고, $15-23^{\circ} \mathrm{C}$ 에서 3 주간 발효를 시킨 후 여과하여 제조하였다. 증류주 제조는 과실발효주(와인)를 증류기에 투 입한 후 상압에서 가온하여 증류액을 취하였다. 1 차 증류는 투입액의 $0.5 \%$ 를 취하여 초류로 분류하고, 본류는 회수되는 증류액이 $10 \%$ 알코올 함량 이하가 될 때까지 진행하였다. 2 차 증류는 1 차 증류시 받은 본류액을 다시 증류기에 투입한 후 1차 증류와 동일하게 진행하였으며, 본류액의 알코올 함 량이 $53 \%$ 가 될 때까지 증류를 실시하였다. 그 이후에 후류는 투입액 기준 $0.5 \%$ 를 회수하였다.

제조된 각각의 증류주는 오크통, 유리병, 스테인리스병에 보관하였다. 숙성은 실온보관으로 온도와 습도를 조절하지 않은 밀실에서 실시하였으며, 총 17 개월간 보관하여 4 회에 걸쳐 분석하였다.

\section{휘발성 향기성분 및 퓨젤유 분석}

각 시료별 휘발성 향기성분, 퓨젤유 및 기타 성분 확인을 위한 표준용액과 각각의 분석시료를 지용성 PTFE syringe filter(17 mm, $0.45 \mu \mathrm{m}$ )로 여과한 다음 GC-FID(Agilent 7890 series, Agilent Technologies, Palo Alto, CA, USA)로 분석하 였다. $\mathrm{GC}$ 분석에 의하여 분리된 각 peak 성분은 표준물질의 머무름 시간과 비교하여 동정하였다. 휘발성 성분의 분리를 위한 column은 INNOWAX(30 $\mathrm{m} \times 0.25 \mathrm{~mm}$ i.d, $0.25 \mu \mathrm{m}$ film thickness, Agilent Technologies)를 사용하였다. Oven의 
온도는 $30^{\circ} \mathrm{C}$ 에서 2 분간 유지한 후, $1^{\circ} \mathrm{C} / \mathrm{min}$ 속도로 $35^{\circ} \mathrm{C}$ 까지 승온시켰다. 다음 $10^{\circ} \mathrm{C} / \mathrm{min}$ 속도로 $150^{\circ} \mathrm{C}$ 까지 승온시켜 3 분 간 유지한 후, $60^{\circ} \mathrm{C} / \mathrm{min}$ 속도로 승온시킨 후 $220^{\circ} \mathrm{C}$ 에서 2 분간 유지하였다. Carrier gas $\left(\mathrm{N}_{2}\right)$ 의 유속은 $45 \mathrm{~mL} / \mathrm{min}$ 로 유지하였 다. $\mathrm{GC}$ injector와 detector 온도는 각각 $200^{\circ} \mathrm{C}, 220^{\circ} \mathrm{C}$ 로 설정 하여 시료 $1.0 \mu \mathrm{L}$ 를 split ratio 50:1로 주입하였고, 검출기는 flame ionization detector(FID)를 사용하였다. 휘발성 향기성 분 및 퓨젤유 등은 국세청 주류면허지원센터 주류분석 규정 에 따라 분석하였다.

\section{지방산 및 지방산 에스테르류 분석}

지방산 및 지방산 에스테르류 분석에 사용된 내부 표준물 질은 $12 \mathrm{mg}$ 의 methyl laurate을 isooctane $500 \mathrm{~mL}$ 에 녹여 제 조하였다. 분석시료 $10 \mathrm{~mL}$ 에 내부 표준물질 $1 \mathrm{~mL}$ 와 $\mathrm{NaCl}$ 약 $1 \mathrm{~g}$ 을 첨가하여 혼합한 후 상등액을 취하여 지용성 PTFE syringe filter(17 mm, $0.45 \mu \mathrm{m})$ 로 여과하고, HP-MS column (30 $\mathrm{m} \times 0.25 \mathrm{~mm}$ i.d, $0.25 \mu \mathrm{m}$ film thickness, Agilent Technologies)이 장착된 GC-MS(Agilent 5975C MSD/7890 GC system, Agilent Technologies)를 이용하여 분석하였다. 사용된 $\mathrm{GC}$ 의 oven 온도는 $50^{\circ} \mathrm{C}$ 에서 1 분간 머무른 뒤, $10^{\circ} \mathrm{C}$ $/ \mathrm{min}$ 의 속도로 $300^{\circ} \mathrm{C}$ 까지 승온시킨 후 5 분간 유지시켰다. Injector 온도는 $250^{\circ} \mathrm{C}$, carrier gas로 $\mathrm{He}$ 을 사용하였다. MSD 조건은 capillary direct interface temperature $290^{\circ} \mathrm{C}$, ion source temperature $250^{\circ} \mathrm{C}$, electron impact(EI) ionization voltage $70 \mathrm{eV}$, mass range 40-550 amu로 설정하였다. GC-MSD로 각 peak의 total ion chromatogram(TIC)를 얻은 후 NIST08 mass spectral database와 비교하여 각각의 성분 을 동정하였으며, 내부 표준물질로 사용된 methyl laurate의 피크 면적을 기준으로 각 성분의 함량비율을 산출하였다.

\section{통계분석}

각 실험은 3 회 반복하여 얻은 결과를 평균 \pm 표준편차로 표 시하였다. 통계분석은 GraphPad Prism 8.0 버전을 이용하여 처리구간의 유의적인 차이를 알아보기 위해 일원분산분석 (One-way anova)을 이용하여 $\mathrm{p}<0.05$ 수준으로 Dunnett's multiple comparisons test로 다중검정을 실시하였다.

\section{결과 및 고찰}

\section{발효주와 증류 단계별 휘발성 향기성분 및 퓨젤유 분석}

머루 또는 다래를 첨가한 발효주를 제조하고 1 차 증류 산 물인 초류(head 1'), 2차 증류 산물인 초류(head 2'), 본류 (body), 후류(tail)를 비교 분석하였다. Table 1, 2는 다래 또 는 머루를 첨가한 증류주의 단계별로 향미성분인 퓨젤유와 휘발성 향기성분인 아세트알데하이드와 메탄올의 함량을 비 교분석하였다.

시료별 아세트알데하이드, 에틸 아세테이트, 메탄올, $n$-프 로판올, 이소부탄올, 이소아밀알코올 성분이 검출되었고 $n$ 부탄올, $n$-아밀알코올의 함유량은 모든 시료에서 검출되지 않았다.

다래의 경우, 휘발성 유해성분인 아세트알데하이드, 에틸 아세테이트, 메탄올은 1차 및 2차 초류에서 유의적으로 크게 증가하였으나 $(\mathrm{p}<0.0001)$, 본류에서는 아세트알데하이드 52.02 $\mathrm{mg} / \mathrm{L}$, 메탄올 $241.11 \mathrm{mg} / \mathrm{L}$ 로 유의적으로 크게 감소하여 $(\mathrm{p}<0.001)$ 국내 증류주 휘발성 유해성분 기준함량(아세트알 데하이드 $700 \mathrm{mg} / \mathrm{L}$ 이하, 메탄올 $1,000 \mathrm{mg} / \mathrm{L}$ 이하) 이하로 나타났다. 에틸 아세테이트도 1, 2차 초류에서 3,099.31 $\mathrm{mg} / \mathrm{L}, 1,602.04 \mathrm{mg} / \mathrm{L}$ 로 유의적으로 높게 나타났으나 $(\mathrm{p}<$ $0.0001)$, 본류에서 $218.64 \mathrm{mg} / \mathrm{L}$ 로 유의적으로 크게 감소하였

Table 1. Major volatile congener ranges of Actinidia arguta brandy

(unit: $\mathrm{mg} / \mathrm{L}$ )

\begin{tabular}{|c|c|c|c|c|c|c|c|c|c|}
\hline $\begin{array}{c}\text { Actinidia } \\
\text { arguta }\end{array}$ & $\begin{array}{l}\text { Acetate } \\
\text { aldehyde }\end{array}$ & $\begin{array}{l}\text { Ethyl } \\
\text { acetate }\end{array}$ & $\begin{array}{l}\text { Methyl } \\
\text { alcohol }\end{array}$ & $\begin{array}{c}n- \\
\text { Propanol }\end{array}$ & $\begin{array}{c}\text { Iso- } \\
\text { butanol }\end{array}$ & $\begin{array}{c}n- \\
\text { Butanol }\end{array}$ & $\begin{array}{l}\text { Isoamyl } \\
\text { alcohol }\end{array}$ & $\begin{array}{l}n \text {-Amyl } \\
\text { alcohol }\end{array}$ & Fusel oils \\
\hline Wine & $\begin{array}{c}15.82 \\
\pm 0.00^{1)}\end{array}$ & $\begin{array}{l}69.90 \\
\pm 0.00\end{array}$ & $\begin{array}{l}56.10 \\
\pm 0.00\end{array}$ & $\begin{array}{l}10.56 \\
\pm 0.00\end{array}$ & $\begin{array}{l}132.24 \\
\pm 0.00\end{array}$ & $\mathrm{ND}^{2)}$ & $\begin{array}{c}272.26 \\
\pm 0.00\end{array}$ & ND & $\begin{array}{c}415.06 \\
\pm 0.13\end{array}$ \\
\hline Head (1') & $\begin{array}{l}331.42 \\
\pm 0.01^{* * * * 3)}\end{array}$ & $\begin{array}{l}3,099.31 \\
\pm 0.05^{* * * *}\end{array}$ & $\begin{array}{l}161.63 \\
\pm 0.07^{* *}\end{array}$ & $\begin{aligned} & 97.59 \\
\pm & 0.00^{* * * *}\end{aligned}$ & $\begin{array}{l}1,532.60 \\
\pm 0.01^{* * * * *}\end{array}$ & ND & $\begin{array}{l}2,777.12 \\
\pm 0.02^{* * * *}\end{array}$ & ND & $\begin{array}{l}4,407.31 \\
\pm 1.34^{* * * *}\end{array}$ \\
\hline Head (2') & $\begin{array}{l}332.93 \\
\pm 0.00^{* * * * *}\end{array}$ & $\begin{array}{l}1,602.04 \\
\pm 0.01^{* * * * *}\end{array}$ & $\begin{array}{c}262.03 \\
\pm 0.00^{* * * *}\end{array}$ & $\begin{aligned} & 89.19 \\
\pm & 0.00^{* * * * *}\end{aligned}$ & $\begin{array}{l}1,193.71 \\
\pm 0.00^{* * * *}\end{array}$ & ND & $\begin{array}{l}1,925.51 \\
\pm 0.01^{* * * *}\end{array}$ & ND & $\begin{array}{l}3,208.41 \\
\pm 0.92^{* * * *}\end{array}$ \\
\hline Body & $\begin{array}{l}52.02 \\
\pm 0.00^{* * *}\end{array}$ & $\begin{array}{l}218.64 \\
\pm 0.00^{* * * *}\end{array}$ & $\begin{array}{l}241.11 \\
\pm 0.00^{* * *}\end{array}$ & $\begin{aligned} & 69.66 \\
& \pm 0.00^{* * * * *}\end{aligned}$ & $\begin{array}{c}647.41 \\
\pm 0.00^{* * * *}\end{array}$ & ND & $\begin{array}{l}1,294.31 \\
\pm 0.01^{* * * *}\end{array}$ & ND & $\begin{array}{l}2,011.38 \\
\pm 0.61^{* * * * *}\end{array}$ \\
\hline Tail & ND & $\begin{array}{l}26.46 \\
\pm 0.01\end{array}$ & $\begin{array}{l}140.40 \\
\pm 0.01^{*}\end{array}$ & $\begin{array}{l}12.18 \\
\pm 0.00\end{array}$ & ND & ND & $\begin{array}{l}76.19 \\
\pm 0.01\end{array}$ & ND & $\begin{array}{l}88.37 \\
\pm 0.05\end{array}$ \\
\hline
\end{tabular}

${ }^{1)}$ Each value is expressed as mean \pm SD $(n=3)$.

${ }^{2)}$ Not detected.

${ }^{3) *} \mathrm{p}<0.05,{ }^{* *} \mathrm{p}<0.01,{ }^{* * *} \mathrm{p}<0.001,{ }^{* * * *} \mathrm{p}<0.0001$. 
Table 2. Major volatile congener ranges of Vitis coignetiae brandy

(unit: $\mathrm{mg} / \mathrm{L}$ )

\begin{tabular}{|c|c|c|c|c|c|c|c|c|c|}
\hline $\begin{array}{c}\text { Vitis } \\
\text { coignetiae }\end{array}$ & $\begin{array}{l}\text { Acetate } \\
\text { aldehyde }\end{array}$ & $\begin{array}{l}\text { Ethyl } \\
\text { acetate }\end{array}$ & $\begin{array}{l}\text { Methyl } \\
\text { alcohol }\end{array}$ & $\begin{array}{c}n- \\
\text { Propanol }\end{array}$ & $\begin{array}{c}\text { Iso- } \\
\text { butanol }\end{array}$ & $\begin{array}{c}n- \\
\text { Butanol }\end{array}$ & $\begin{array}{l}\text { Isoamyl } \\
\text { alcohol }\end{array}$ & $\begin{array}{l}n \text {-Amyl } \\
\text { alcohol }\end{array}$ & Fusel oils \\
\hline Wine & $\begin{array}{c}11.22 \\
\pm 0.00^{1)}\end{array}$ & $\begin{array}{l}61.66 \\
\pm 0.00\end{array}$ & $\begin{array}{l}75.74 \\
\pm 0.01\end{array}$ & $\begin{array}{l}23.26 \\
\pm 0.00\end{array}$ & $\begin{array}{l}68.45 \\
\pm 0.00\end{array}$ & $\mathrm{ND}^{2)}$ & $\begin{array}{c}220.11 \\
\pm 0.00\end{array}$ & ND & $\begin{array}{c}311.82 \\
\pm 0.10\end{array}$ \\
\hline Head (1') & $\begin{array}{c}461.75 \\
\pm 0.00^{* * * * 3)}\end{array}$ & $\begin{array}{l}2,612.09 \\
\pm 0.03^{* * * * *}\end{array}$ & $\begin{array}{c}138.18 \\
\pm 0.07\end{array}$ & $\begin{array}{l}131.23 \\
\pm 0.00^{* * * * *}\end{array}$ & $\begin{array}{l}556.84 \\
\pm 0.00^{* * * * *}\end{array}$ & ND & $\begin{array}{l}1,475.43 \\
\pm 0.01^{* * * * *}\end{array}$ & ND & $\begin{array}{l}2,163.50 \\
\pm 0.69^{* * * *}\end{array}$ \\
\hline Head (2') & $\begin{array}{c}524.90 \\
\pm 0.01^{* * * * *}\end{array}$ & $\begin{array}{l}1,617.35 \\
\pm 0.01^{* * * * *}\end{array}$ & $\begin{array}{c}286.40 \\
\pm 0.00^{* * * * *}\end{array}$ & $\begin{array}{l}111.14 \\
\pm 0.00^{* * * * *}\end{array}$ & $\begin{array}{l}378.90 \\
\pm 0.00^{* * * * *}\end{array}$ & ND & $\begin{array}{l}861.25 \\
\pm 0.01^{* * * * *}\end{array}$ & ND & $\begin{array}{l}1,351.29 \\
\pm 0.38^{* * * * *}\end{array}$ \\
\hline Body & $\begin{array}{l}38.16 \\
\pm 0.02^{*}\end{array}$ & $\begin{array}{l}255.58 \\
\pm 0.00^{* * * * * *}\end{array}$ & $\begin{array}{l}272.23 \\
\pm 0.00^{* * * * *}\end{array}$ & $\begin{array}{l}107.96 \\
\pm 0.00^{* * * * *}\end{array}$ & $\begin{array}{l}281.01 \\
\pm 0.00^{* * * * *}\end{array}$ & ND & $\begin{array}{l}898.33 \\
\pm 0.01^{* * * * *}\end{array}$ & ND & $\begin{array}{l}1,287.30 \\
\pm 0.42^{* * * * *}\end{array}$ \\
\hline Tail & $\mathrm{ND}$ & $\begin{array}{l}28.48 \\
\pm 0.01\end{array}$ & $\begin{array}{c}140.91 \\
\pm 0.01\end{array}$ & $\begin{array}{l}24.37 \\
\pm 0.00\end{array}$ & ND & ND & $\begin{array}{l}156.02 \\
\pm 0.01^{* * * * *}\end{array}$ & ND & $\begin{array}{c}180.39 \\
\pm 0.09^{* * * * *}\end{array}$ \\
\hline
\end{tabular}

${ }^{1)}$ Each value is expressed as mean $\pm \mathrm{SD}(\mathrm{n}=3)$.

${ }^{2)}$ Not detected.

${ }^{3)} \mathrm{p}<0.05,{ }^{* *} \mathrm{p}<0.01,{ }^{* * *} \mathrm{p}<0.001,{ }^{* * * *} \mathrm{p}<0.0001$.

다 $(\mathrm{p}<0.0001)$. 퓨젤유 함유량은 1 차, 2 차 초류 단계에는 각각 $4,407.31 \mathrm{mg} / \mathrm{L}, 3,208.41 \mathrm{mg} / \mathrm{L}$ 값이 검출되어 각 과정 중에 서 함유량이 유의적으로 높게 나타났고 $(\mathrm{p}<0.0001)$, 본류 단 계는 $2,011.38 \mathrm{mg} / \mathrm{L}$ 로 과실주 대비 유의적으로 높게 나타났 다 $(\mathrm{p}<0.0001)$.

머루의 경우에는 휘발성 유해성분인 아세트알데하이드, 에틸 아세테이트, 메탄올이 다래와 유사한 경향을 보이며, 퓨 젤유 함유량은 1차, 2차 초류 단계에서 각각 $2,163.50 \mathrm{mg} / \mathrm{L}$, $1,351.29 \mathrm{mg} / \mathrm{L}$ 로 유의적으로 크게 증가하였고 $(\mathrm{p}<0.0001)$, 본 류에서는 $1,287.30 \mathrm{mg} / \mathrm{L}$ 값이 검출되었다 $(\mathrm{p}<0.0001)$.

\section{증류주의 숙성용기 및 숙성기간별 휘발성 향기성분 및 퓨젤유 분석}

다래 또는 머루를 함유한 증류주의 숙성용기별(오크통, 유
리병, 스테인리스 $)$, 기간별 $(0,3,7,11,17$ 개월 $)$ 휘발성 향기 성분 3종(아세트알데하이드, 에틸 아세테이트, 메탄올), 퓨젤 유 5 종 ( $n$-프로판올, 이소부탄올, $n$-부탄올, 이소아밀알코올, $n$-아밀알코올)을 $\mathrm{GC}$ 장비를 이용하여 분석하였다. 모든 분 석시료에서 아세트알데하이드, 에틸 아세테이트, 메탄올, $n$ 프로판올, 이소부탄올, 이소아밀알코올이 검출되었다.

다래 첨가 증류주의 퓨젤유 $n$-프로판올, 이소부탄올, $n$-부 탄올, 이소아밀알코올, $n$-아밀알코올) 분석결과, 스테인리스, 유리병에서는 퓨젤유 성분은 큰 차이는 나타나지 않았으며, 오크통에서 17 개월 동안 보관한 시료의 총 퓨젤유 함량이 $6,274.24 \mathrm{mg} / \mathrm{L}$ 로 높게 나타났다(Table 3). 오크통에서 숙성 될수록 이소부탄올은 $647.41 \mathrm{mg} / \mathrm{L}$ 에서 $1,944.21 .78 \mathrm{mg} / \mathrm{L}$ 로 유의적으로 높게 증가하였으며(p<0.0001), 이소아밀알코올 의 경우에는 $1,294.31 \mathrm{mg} / \mathrm{L}$ 에서 $4,125.36 \mathrm{mg} / \mathrm{L}$ 로 유의적으

Table 3. Major volatile congener ranges of Actinidia arguta brandy

(unit: $\mathrm{mg} / \mathrm{L}$ )

\begin{tabular}{|c|c|c|c|c|c|c|c|c|c|}
\hline \multirow[b]{2}{*}{$\begin{array}{c}\text { Actinidia } \\
\text { arguta }\end{array}$} & \multirow{2}{*}{$\begin{array}{c}\text { Maturation } \\
\text { period } \\
\text { (month) }\end{array}$} & \multirow{2}{*}{$\begin{array}{l}\text { Acetate } \\
\text { aldehyde }\end{array}$} & \multirow{2}{*}{$\begin{array}{c}\text { Ethyl } \\
\text { acetate }\end{array}$} & \multirow{2}{*}{$\begin{array}{l}\text { Methyl } \\
\text { alcohol }\end{array}$} & \multicolumn{5}{|c|}{ Fusel oils } \\
\hline & & & & & $\begin{array}{c}n- \\
\text { Propanol }\end{array}$ & $\begin{array}{c}\text { Iso- } \\
\text { butanol }\end{array}$ & $\begin{array}{c}n- \\
\text { Butanol }\end{array}$ & $\begin{array}{l}\text { Isoamyl } \\
\text { alcohol }\end{array}$ & $\begin{array}{l}n \text {-Amyl } \\
\text { alcohol }\end{array}$ \\
\hline Initial & 0 & $\begin{array}{c}52.02 \\
\pm 0.00^{1)}\end{array}$ & $\begin{array}{c}218.64 \\
\pm 0.00\end{array}$ & $\begin{array}{c}241.11 \\
\pm 0.00\end{array}$ & $\begin{array}{l}69.66 \\
\pm 0.00\end{array}$ & $\begin{array}{c}647.41 \\
\pm 0.00\end{array}$ & $\mathrm{ND}^{2)}$ & $\begin{array}{c}1,294.31 \\
\pm 0.01\end{array}$ & ND \\
\hline \multirow{4}{*}{ Oak } & 3 & $\begin{array}{c}22.52 \\
\pm 0.01^{* * * * 3)}\end{array}$ & $\begin{array}{l}190.22 \\
\pm 0.01\end{array}$ & $\begin{array}{c}269.63 \\
\pm 0.14\end{array}$ & $\begin{array}{l}65.92 \\
\pm 0.00\end{array}$ & $\begin{array}{c}625.41 \\
\pm 0.04\end{array}$ & $\begin{array}{c}4.71 \\
\pm 0.00 \text { **** }\end{array}$ & $\begin{array}{c}1,236.33 \\
\pm 0.08\end{array}$ & ND \\
\hline & 7 & $\begin{array}{l}12.52 \\
\pm 0.00^{* * * * *}\end{array}$ & $\begin{array}{c}242.73 \\
\pm 0.00\end{array}$ & $\begin{array}{c}237.29 \\
\pm 0.00\end{array}$ & $\begin{array}{l}201.94 \\
\pm 0.01^{* * * *}\end{array}$ & $\begin{array}{l}715.96 \\
\pm 0.00^{* * * * *}\end{array}$ & $\begin{array}{c}14.61 \\
\pm 0.00 * * * *\end{array}$ & $\begin{array}{c}1,421.44 \\
\pm 0.00^{*}\end{array}$ & ND \\
\hline & 11 & ND & $\begin{array}{l}184.43 \\
\pm 0.03^{*}\end{array}$ & $\begin{array}{l}113.33 \\
\pm 0.02\end{array}$ & $\begin{array}{l}88.51 \\
\pm 0.00^{* * *}\end{array}$ & $\begin{array}{l}1,023.66 \\
\pm 0.04^{* * * *}\end{array}$ & $\begin{array}{c}28.64 \\
\pm 0.00^{* * * *}\end{array}$ & $\begin{array}{l}2,065.25 \\
\pm 0.09^{* * * *}\end{array}$ & ND \\
\hline & 17 & ND & $\begin{array}{c}224.65 \\
\pm 0.00\end{array}$ & ND & $\begin{array}{l}149.78 \\
\pm 0.00^{* * * * *}\end{array}$ & $\begin{array}{c}1,944.21 \\
\pm 0.04\end{array}$ & $\begin{array}{c}54.89 \\
\pm 0.00^{* * * *}\end{array}$ & $\begin{array}{l}4,125.36 \\
\pm 0.02^{* * * *}\end{array}$ & ND \\
\hline
\end{tabular}


(continued)

\begin{tabular}{|c|c|c|c|c|c|c|c|c|c|}
\hline \multirow{2}{*}{$\begin{array}{l}\text { Actinidia } \\
\text { arguta }\end{array}$} & \multirow{2}{*}{$\begin{array}{c}\text { Maturation } \\
\text { period } \\
\text { (month) }\end{array}$} & \multirow{2}{*}{$\begin{array}{l}\text { Acetate } \\
\text { aldehyde }\end{array}$} & \multirow{2}{*}{$\begin{array}{l}\text { Ethyl } \\
\text { acetate }\end{array}$} & \multirow{2}{*}{$\begin{array}{l}\text { Methyl } \\
\text { alcohol }\end{array}$} & \multicolumn{5}{|c|}{ Fusel oils } \\
\hline & & & & & $\begin{array}{c}n- \\
\text { Propanol }\end{array}$ & $\begin{array}{c}\text { Iso- } \\
\text { butanol }\end{array}$ & $\begin{array}{c}n- \\
\text { Butanol }\end{array}$ & $\begin{array}{l}\text { Isoamyl } \\
\text { alcohol }\end{array}$ & $\begin{array}{l}n \text {-Amyl } \\
\text { alcohol }\end{array}$ \\
\hline \multirow{4}{*}{ Stainless } & 3 & $\begin{array}{l}20.88 \\
\pm 0.00^{* * * * *}\end{array}$ & $\begin{array}{l}176.84 \\
\pm 0.01^{* * * *}\end{array}$ & $\begin{array}{l}404.13 \\
\pm 0.02^{* * * * *}\end{array}$ & $\begin{array}{l}63.93 \\
\pm 0.00\end{array}$ & $\begin{array}{c}616.68 \\
\pm 0.03\end{array}$ & ND & $\begin{array}{l}1,211.28 \\
\pm 0.05^{* *}\end{array}$ & ND \\
\hline & 7 & ND & $\begin{array}{l}151.33 \\
\pm 0.00^{* * * * *}\end{array}$ & $\begin{array}{c}241.25 \\
\pm 0.00\end{array}$ & $\begin{array}{l}134.94 \\
\pm 0.05^{* *}\end{array}$ & $\begin{array}{l}612.02 \\
\pm 0.00^{*}\end{array}$ & ND & $\begin{array}{l}1,210.88 \\
\pm 0.00^{* *}\end{array}$ & ND \\
\hline & 11 & ND & $\begin{array}{l}71.33 \\
\pm 0.00^{* * * * *}\end{array}$ & $\begin{array}{l}196.68 \\
\pm 0.00^{* *}\end{array}$ & $\begin{array}{l}63.48 \\
\pm 0.00\end{array}$ & $\begin{array}{c}630.10 \\
\pm 0.00\end{array}$ & ND & $\begin{array}{c}1,238.62 \\
\pm 0.01\end{array}$ & ND \\
\hline & 17 & ND & $\begin{array}{l}91.62 \\
\pm 0.00^{* * * *}\end{array}$ & $\begin{array}{c}238.00 \\
\pm 0.00\end{array}$ & $\begin{array}{l}62.59 \\
\pm .000\end{array}$ & $\begin{array}{c}619.54 \\
\pm 0.00\end{array}$ & ND & $\begin{array}{c}1,215.49 \\
\pm 0.00^{*}\end{array}$ & ND \\
\hline \multirow{4}{*}{ Glass } & 3 & $\begin{array}{l}24.27 \\
\pm 0.00^{* * * * *}\end{array}$ & $\begin{array}{l}221.85 \\
\pm 0.00\end{array}$ & $\begin{array}{l}389.18 \\
\pm 0.01^{* * * * *}\end{array}$ & $\begin{array}{l}62.00 \\
\pm 0.00^{* * * *}\end{array}$ & $\begin{array}{l}595.74 \\
\pm 0.01^{* * * *}\end{array}$ & ND & $\begin{array}{l}1,170.62 \\
\pm 0.02^{* * * * *}\end{array}$ & ND \\
\hline & 7 & $\begin{array}{l}29.68 \\
\pm 0.00^{* * * * *}\end{array}$ & $\begin{array}{l}109.64 \\
\pm 0.00^{* * * * *}\end{array}$ & $\begin{array}{l}252.98 \\
\pm 0.00^{*}\end{array}$ & $\begin{array}{l}163.16 \\
\pm 0.00^{* * * * *}\end{array}$ & $\begin{array}{l}619.64 \\
\pm 0.00^{* *}\end{array}$ & ND & $\begin{array}{l}1,223.09 \\
\pm 0.00^{* * * *}\end{array}$ & ND \\
\hline & 11 & $\begin{array}{l}51.77 \\
\pm 0.00\end{array}$ & $\begin{array}{l}139.12 \\
\pm 0.00^{* * * * *}\end{array}$ & $\begin{array}{l}134.11 \\
\pm 0.00^{* * * *}\end{array}$ & $\begin{array}{l}62.40 \\
\pm 0.00^{* * * * *}\end{array}$ & $\begin{array}{c}633.92 \\
\pm 0.01\end{array}$ & ND & $\begin{array}{l}1,242.27 \\
\pm 0.01^{* * *}\end{array}$ & ND \\
\hline & 17 & $\begin{array}{l}49.12 \\
\pm 0.00\end{array}$ & $\begin{array}{l}114.12 \\
\pm 0.00^{* * * * *}\end{array}$ & $\begin{array}{l}254.39 \\
\pm 0.00^{*}\end{array}$ & $\begin{array}{c}62.63 \\
\pm 0.00^{* * * *}\end{array}$ & $\begin{array}{l}630.63 \\
\pm 0.01^{*}\end{array}$ & ND & $\begin{array}{l}1,228.08 \\
\pm 0.01^{* * * *}\end{array}$ & ND \\
\hline
\end{tabular}

${ }^{1)}$ Each value is expressed as mean $\pm \mathrm{SD}(\mathrm{n}=3)$.

${ }^{2)}$ Not detected.

${ }^{3)^{*}} \mathrm{p}<0.05,{ }^{* *} \mathrm{p}<0.01,{ }^{* * *} \mathrm{p}<0.001,{ }^{* * * *} \mathrm{p}<0.0001$.

로 증가하는 경향을 보였다 $(\mathrm{p}<0.0001)$. 다래 첨가 증류주의 $n$-부탄올은 숙성초기에는 검출되지 않았으며, 오크통에서 숙 성될수록 유의적으로 증가한 반면( $\mathrm{p}<0.0001)$, 스테인리스와 유리병에서는 생성되지 않음을 확인하였다. $n$-아밀알코올은 모든 시료에서 확인되지 않았으며, 자극적인 향의 주요 원인 인 아세트알데하이드는 오크통에 저장할수록 유의적으로 급 격히 감소하는 것을 확인하였다.

머루 첨가 증류주의 퓨젤유 $n$-프로판올, 이소부탄올, $n$-부 탄올, 이소아밀알코올, $n$-아밀알코올) 분석결과, 다래 첨가 증류주와 비교하여 스테인리스, 유리병에서는 퓨젤유 검출량 의 차이가 크지 않았으나, 오크통에서 17 개월 동안 보관한 시 료의 총 퓨젤유 함량이 $2,419.76 \mathrm{mg} / \mathrm{L}$ 로 높게 검출되었다 (Table 4). 오크통에서 숙성될수록 이소부탄올은 $281.01 \mathrm{mg} / \mathrm{L}$ 에서 $687.88 \mathrm{mg} / \mathrm{L}$ 로 유의적으로 높았고 $(\mathrm{p}<0.0001)$, 이소아 밀알코올의 경우에는 $898.33 \mathrm{mg} / \mathrm{L}$ 에서 $1,605.57 \mathrm{mg} / \mathrm{L}$ 로 유 의적으로 증가하는 경향을 보였다 $(\mathrm{p}<0.0001)$. 머루 첨가 증 류주의 $n$-부탄올은 숙성초기에는 검출되지 않았으며, 오크통 에서 숙성될수록 유의적으로 증가한 반면 $(\mathrm{p}<0.0001)$, 스테인 리스와 유리병에서 생성되지 않음을 확인하였다. $n$-아밀알코 올은 불검출되었으며, 아세트알데하이드도 다래 첨가 증류주 와 동일하게 오크통에 저장할수록 급격히 감소하였다.

퓨젤유 성분 중 이소아밀알코올은 다래 첨가 증류주의 경
우, 숙성시작 전에는 $1,294.31 \mathrm{mg} / \mathrm{L}$ 에서 17 개월 숙성 후 $4,125.36 \mathrm{mg} / \mathrm{L}$ 로 초기대비 약 $218 \%$ 증가하였으며, 머루 첨 가 증류주의 경우 숙성시작 전에는 $898.33 \mathrm{mg} / \mathrm{L}$ 에서 17 개월 숙성 후 $1,605.57 \mathrm{mg} / \mathrm{L}$ 로 약 $178 \%$ 증가하였다. 이 결과는 원 료 중 단백질 분해 생성물인 아미노산으로부터 알코올 발효시 효모에 의해 탈아미노기 반응(deamination)과 동시에 탈카르 복실 반응(decarboxylation)에 의해서 생성되는 퓨젤유의 약 $50 \%$ 이상이 amyl alcohol로 생성되는 기존의 연구결과(Choi, 2004)와 일치한다. 숙성용기에 따른 발효 산물의 특성 변화는 다양한 연구를 통해 이미 보고되었으며, 특히, 오크통을 사용 한 발효주는 타 용기 대비 알코올 및 손실량이 큰 반면, 퓨젤 유계 함량과 오크통과의 반응으로 특유의 향기성분을 증가시 키는 것으로 보고되고 있다(Kang, 2017; Lee, 2014).

탄소수가 많은 고급알코올인 퓨젤유는 아미노산이 알코올 발효시의 효모에 의한 탈아미노기(deamination) 반응과 동시 에 탈카르복시(decarboxylation) 반응에 의해서 생성된다(Kim, 2017). 다래증류주의 본류 퓨젤유 함량 $(2,011.38 \mathrm{mg} / \mathrm{L})$ 이 머 루증류주의 본류 $(1,287.30 \mathrm{mg} / \mathrm{L})$ 보다 약 1.5 배 높게 나타났 으며, 이는 원료 중의 아미노산 함유량 등의 특성에 기인한 것으로 보인다(Ryu 등, 1987). 오크통의 주원료인 참나무의 수지 및 목재의 주요성분인 타닌, 리그린 성분이 숙성과정에 서 용출되고, 증류주의 당분, 산, 알코올 및 페놀류 성분과 화 
Table 4. Major volatile congener ranges of Vitis coignetiae brandy

(unit: $\mathrm{mg} / \mathrm{L}$ )

\begin{tabular}{|c|c|c|c|c|c|c|c|c|c|}
\hline \multirow[b]{2}{*}{$\begin{array}{c}\text { Vitis } \\
\text { coignetiae }\end{array}$} & \multirow{2}{*}{$\begin{array}{c}\text { Maturation } \\
\text { period } \\
\text { (month) }\end{array}$} & \multirow[b]{2}{*}{$\begin{array}{l}\text { Acet- } \\
\text { aldehyde }\end{array}$} & \multirow[b]{2}{*}{$\begin{array}{l}\text { Ethyl } \\
\text { acetate }\end{array}$} & \multirow[b]{2}{*}{$\begin{array}{l}\text { Methyl } \\
\text { alcohol }\end{array}$} & \multicolumn{5}{|c|}{ Fusel oils } \\
\hline & & & & & $\begin{array}{c}n- \\
\text { Propanol }\end{array}$ & $\begin{array}{c}\text { Iso- } \\
\text { butanol }\end{array}$ & $\begin{array}{c}n- \\
\text { Butanol }\end{array}$ & $\begin{array}{l}\text { Isoamyl } \\
\text { alcohol }\end{array}$ & $\begin{array}{l}n \text {-Amyl } \\
\text { alcohol }\end{array}$ \\
\hline Initial & 0 & $\begin{array}{c}38.16 \\
\pm 0.02^{1)}\end{array}$ & $\begin{array}{c}255.58 \\
\pm 0.00\end{array}$ & $\begin{array}{c}272.23 \\
\pm 0.00\end{array}$ & $\begin{array}{l}107.96 \\
\pm 0.00\end{array}$ & $\begin{array}{c}281.01 \\
\pm 0.00\end{array}$ & $\mathrm{ND}^{2)}$ & $\begin{array}{c}898.33 \\
\pm 0.01\end{array}$ & ND \\
\hline \multirow{4}{*}{ Oak } & 3 & $\begin{array}{l}28.52 \\
\pm 0.00\end{array}$ & $\begin{array}{c}237.17 \\
\pm 0.01\end{array}$ & $\begin{array}{c}405.86 \\
\pm 0.12\end{array}$ & $\begin{array}{l}103.61 \\
\pm 0.00\end{array}$ & $\begin{array}{c}287.43 \\
\pm 0.01\end{array}$ & $\begin{array}{c}7.31 \\
\pm 0.00^{*}\end{array}$ & $\begin{array}{c}905.86 \\
\pm 0.04\end{array}$ & ND \\
\hline & 7 & $\begin{array}{c}12.79 \\
\pm 0.00^{* 3)}\end{array}$ & $\begin{array}{l}101.77 \\
\pm 0.00^{* *}\end{array}$ & $\begin{array}{l}142.92 \\
\pm 0.10\end{array}$ & $\begin{array}{l}353.81 \\
\pm 0.00^{* * * *}\end{array}$ & $\begin{array}{c}314.73 \\
\pm 0.00\end{array}$ & $\begin{array}{l}21.06 \\
\pm 0.00^{* * * * *}\end{array}$ & $\begin{array}{c}1,007.16 \\
\pm 0.00\end{array}$ & ND \\
\hline & 11 & ND & $\begin{array}{l}137.09 \\
\pm 0.08^{* *}\end{array}$ & $\begin{array}{l}23.05 \\
\pm 0.04^{* *}\end{array}$ & $\begin{array}{l}149.30 \\
\pm 0.02^{* * * *}\end{array}$ & $\begin{array}{l}504.19 \\
\pm 0.06^{* * * *}\end{array}$ & $\begin{array}{l}44.50 \\
\pm 0.01^{* * * * *}\end{array}$ & $\begin{array}{l}1,642.08 \\
\pm 0.20^{* * * * *}\end{array}$ & ND \\
\hline & 17 & ND & $\begin{array}{l}118.68 \\
\pm 0.00^{* *}\end{array}$ & $\begin{array}{l}71.12 \\
\pm 0.00^{*}\end{array}$ & $\begin{array}{l}106.96 \\
\pm 0.00\end{array}$ & $\begin{array}{l}687.88 \\
\pm 0.01^{* * * *}\end{array}$ & $\begin{array}{l}19.35 \\
\pm 0.00^{* * * *}\end{array}$ & $\begin{array}{l}1,605.57 \\
\pm 0.01^{* * * *}\end{array}$ & ND \\
\hline \multirow{4}{*}{ Stainless } & 3 & $\begin{array}{l}26.68 \\
\pm 0.00\end{array}$ & $\begin{array}{c}250.30 \\
\pm 0.01\end{array}$ & $\begin{array}{l}471.53 \\
\pm 0.02^{* * * *}\end{array}$ & $\begin{array}{l}99.18 \\
\pm 0.00\end{array}$ & $\begin{array}{c}276.22 \\
\pm 0.01\end{array}$ & ND & $\begin{array}{l}873.50 \\
\pm 0.04\end{array}$ & ND \\
\hline & 7 & $\begin{array}{c}13.59 \\
\pm 0.00^{*}\end{array}$ & $\begin{array}{l}104.63 \\
\pm 0.00^{* * * * *}\end{array}$ & $\begin{array}{c}282.97 \\
\pm 0.00\end{array}$ & $\begin{array}{l}290.08 \\
\pm 0.01^{* * * *}\end{array}$ & $\begin{array}{c}269.65 \\
\pm 0.00\end{array}$ & ND & $\begin{array}{c}859.49 \\
\pm 0.00\end{array}$ & ND \\
\hline & 11 & $\begin{array}{c}12.73 \\
\pm 0.00^{*}\end{array}$ & $\begin{array}{l}84.72 \\
\pm 0.00^{* * * *}\end{array}$ & $\begin{array}{l}172.59 \\
\pm 0.00^{* * * *}\end{array}$ & $\begin{array}{l}95.72 \\
\pm 0.00^{*}\end{array}$ & $\begin{array}{c}276.74 \\
\pm 0.00\end{array}$ & ND & $\begin{array}{c}876.83 \\
\pm 0.00\end{array}$ & ND \\
\hline & 17 & $\begin{array}{l}19.06 \\
\pm 0.01\end{array}$ & $\begin{array}{l}115.39 \\
\pm 0.00^{* * * *}\end{array}$ & $\begin{array}{c}279.09 \\
\pm 0.00\end{array}$ & $\begin{array}{l}93.96 \\
\pm 0.00^{*}\end{array}$ & $\begin{array}{c}272.13 \\
\pm 0.00\end{array}$ & ND & $\begin{array}{c}864.75 \\
\pm 0.00\end{array}$ & ND \\
\hline \multirow{4}{*}{ Glass } & 3 & $\begin{array}{l}56.94 \\
\pm 0.03\end{array}$ & $\begin{array}{l}318.37 \\
\pm 0.01^{* * * *}\end{array}$ & $\begin{array}{l}441.24 \\
\pm 0.01^{* * * *}\end{array}$ & $\begin{array}{l}94.00^{* * *} \\
\pm 0.00^{\text {. }}\end{array}$ & $\begin{array}{l}259.87 \\
\pm 0.01^{* * *}\end{array}$ & ND & $\begin{array}{l}822.51 \\
\pm 0.02^{* * * *}\end{array}$ & ND \\
\hline & 7 & $\begin{array}{l}39.99 \\
\pm 0.00\end{array}$ & $\begin{array}{l}103.18 \\
\pm 0.00^{* * * * *}\end{array}$ & $\begin{array}{c}298.73 \\
\pm 0.00\end{array}$ & $\begin{array}{l}286.63 \\
\pm 0.00^{* * * * *}\end{array}$ & $\begin{array}{c}270.34 \\
\pm 0.00\end{array}$ & ND & $\begin{array}{l}860.04 \\
\pm 0.00^{*}\end{array}$ & ND \\
\hline & 11 & $\begin{array}{l}47.84 \\
\pm 0.00\end{array}$ & $\begin{array}{l}145.12 \\
\pm 0.00^{* * * *}\end{array}$ & $\begin{array}{l}16.83 \\
\pm 0.00^{* * * *}\end{array}$ & $\begin{array}{l}93.48 \\
\pm 0.00^{* * *}\end{array}$ & $\begin{array}{c}276.86 \\
\pm 0.00\end{array}$ & ND & $\begin{array}{c}876.49 \\
\pm 0.01\end{array}$ & ND \\
\hline & 17 & $\begin{array}{l}39.30 \\
\pm 0.01\end{array}$ & $\begin{array}{c}69.47 \\
\pm 0.00^{* * * *}\end{array}$ & $\begin{aligned} & 29.31 \\
\pm 0.03 & \text { ***** }\end{aligned}$ & $\begin{array}{c}93.46 \\
\pm 0.00^{* * * *}\end{array}$ & $\begin{array}{l}268.99 \\
\pm 0.00^{*}\end{array}$ & ND & $\begin{array}{c}880.74 \\
\pm 0.00\end{array}$ & ND \\
\hline
\end{tabular}

${ }^{1)}$ Each value is expressed as mean \pm SD $(n=3)$.

${ }^{2)}$ Not detected.

${ }^{3)} \mathrm{p}<0.05,{ }^{* *} \mathrm{p}<0.01,{ }^{* * *} \mathrm{p}<0.001,{ }^{* * * *} \mathrm{p}<0.0001$.

학반응을 통해 오크통에 숙성한 증류주 특유의 맛과 향을 생 성해낸다(Park, 1995).

본 연구결과에서도 다래와 머루 종에 상관없이 오크통 용 기를 사용한 발효숙성은 스테인리스와 유리병 용기에서의 숙 성 대비 퓨젤유계 함량을 증가시켰고, 자극적 향기성분인 아 세트알데하이드 함량 감소 결과가 나타나 결론적으로 숙성과 정에서 숙성용기가 다래와 머루 모두 맛과 향기를 높인 브랜 디 개발에 중요한 요소이며, 상품가치를 높이는데 기여할 것 으로 생각된다.

\section{Isoamyl alcohol(a)과 isobutanol(b)의 $a / b$ ratio 비교 분석}

특히 퓨젤유 성분 중 isoamyl alcohol(a)과 isobutanol(b)은 $\mathrm{a} / \mathrm{b}$ ratio로 증류주의 종류에 따라 독특한 향기를 나타내는 일 정한 비율을 갖는 것으로 알려져 있다(Lee 등, 1989). 본 연 구 결과, 다래 및 머루 브랜디의 경우에는 a/b ratio가 약 2-3 으로 나타났으며(Table 5, 6), 이는 과실 브랜디의 품질지표 로 활용될 수 있음을 시사한다.

\section{머루 첨가 증류주의 숙성기간별 지방산 에스테르류 분석}

증류주는 숙성 초기 자극적인 향과 맛을 가지며 숙성을 통 해 물과 알코올의 회합, 카르보닐 화합물과 지방산의 에스테 르화 반응으로 향기성분이 생성되며, 맛과 향미가 향상되는 것으로 알려져 있다(Kim과 Lee, 2019). 본 연구에서 GC-MS 를 통해 분석한 결과, 지방산 에스테르류가 머루발효주와 숙 성초기단계에서는 검출되지 않았으며, 숙성과정에서 생성되 
Table 5. Change of fusel oils in storege vessel during maturation period of Actinidia arguta brandy

(unit: $\mathrm{mg} / \mathrm{L}$ )

\begin{tabular}{|c|c|c|c|c|c|c|c|c|c|}
\hline \multirow{2}{*}{$\begin{array}{l}\text { Maturation } \\
\text { period } \\
\text { (month) }\end{array}$} & \multicolumn{3}{|c|}{ Isobutanol } & \multicolumn{3}{|c|}{ Isoamyl alcohol } & \multicolumn{3}{|c|}{$\mathrm{a} / \mathrm{b} \mathrm{ratio}^{2)}$} \\
\hline & Oak & Stainless & Glass & Oak & Stainless & Glass & Oak & Stainless & Glass \\
\hline 0 & $\begin{array}{l}647.41 \\
\pm 0.00^{1)}\end{array}$ & $\begin{array}{c}647.41 \\
\pm 0.00\end{array}$ & $\begin{array}{c}647.41 \\
\pm 0.00\end{array}$ & $\begin{array}{c}1,294.31 \\
\pm 0.01\end{array}$ & $\begin{array}{c}1,294.31 \\
\pm 0.01\end{array}$ & $\begin{array}{c}1,294.31 \\
\pm 0.01\end{array}$ & $\begin{array}{c}2.00 \\
\pm 0.02\end{array}$ & $\begin{array}{c}2.00 \\
\pm 0.02\end{array}$ & $\begin{array}{c}2.00 \\
\pm 0.02\end{array}$ \\
\hline 3 & $\begin{array}{c}625.41 \\
\pm 0.04\end{array}$ & $\begin{array}{l}616.68 \\
\pm 0.03\end{array}$ & $\begin{array}{c}595.74 \\
\pm 0.01^{* * * * 3)}\end{array}$ & $\begin{array}{c}1,236.33 \\
\pm 0.08\end{array}$ & $\begin{array}{l}1,211.28 \\
\pm 0.05^{* *}\end{array}$ & $\begin{array}{l}1,170.62 \\
\pm 0.02^{* * * * *}\end{array}$ & $\begin{array}{c}1.98 \\
\pm 0.02\end{array}$ & $\begin{array}{c}1.96 \\
\pm 0.02\end{array}$ & $\begin{array}{c}1.96 \\
\pm 0.01\end{array}$ \\
\hline 7 & $\begin{array}{c}715.96 \\
\pm 0.00^{* * * * *}\end{array}$ & $\begin{array}{l}612.02 \\
\pm 0.00\end{array}$ & $\begin{array}{l}619.64 \\
\pm 0.00^{* * *}\end{array}$ & $\begin{array}{c}1,421.44 \\
\pm 0.00^{*}\end{array}$ & $\begin{array}{l}1,210.88 \\
\pm 0.00^{* *}\end{array}$ & $\begin{array}{l}1,223.09 \\
\pm 0.00^{* * *}\end{array}$ & $\begin{array}{c}1.99 \\
\pm 0.02\end{array}$ & $\begin{array}{c}1.98 \\
\pm 0.00\end{array}$ & $\begin{array}{c}1.97 \\
\pm 0.01\end{array}$ \\
\hline 11 & $\begin{array}{l}1,023.66 \\
\pm 0.04^{* * * * *}\end{array}$ & $\begin{array}{c}630.10 \\
\pm 0.00\end{array}$ & $\begin{array}{c}633.92 \\
\pm 0.01\end{array}$ & $\begin{array}{l}2,065.25 \\
\pm 0.09^{* * * * *}\end{array}$ & $\begin{array}{c}1,238.62 \\
\pm 0.01\end{array}$ & $\begin{array}{l}1,242.27 \\
\pm 0.01^{* *}\end{array}$ & $\begin{array}{c}2.02 \\
\pm 0.01\end{array}$ & $\begin{array}{c}1.97 \\
\pm 0.02\end{array}$ & $\begin{array}{c}1.96 \\
\pm 0.01\end{array}$ \\
\hline 17 & $\begin{array}{c}1,944.21 \\
\pm 0.04\end{array}$ & $\begin{array}{c}619.54 \\
\pm 0.00\end{array}$ & $\begin{array}{l}630.63 \\
\pm 0.01^{*}\end{array}$ & $\begin{array}{l}4,125.36 \\
\pm 0.02^{* * * *}\end{array}$ & $\begin{array}{c}1,215.49 \\
\pm 0.00^{*}\end{array}$ & $\begin{array}{l}1,228.08 \\
\pm 0.01^{* * *}\end{array}$ & $\begin{array}{c}2.12 \\
\pm 0.04\end{array}$ & $\begin{array}{c}1.96 \\
\pm 0.01\end{array}$ & $\begin{array}{c}1.95 \\
\pm 0.02\end{array}$ \\
\hline
\end{tabular}

${ }^{1)}$ Each value is expressed as mean $\pm \mathrm{SD}(\mathrm{n}=3)$.

${ }^{2)}$ Ratio = Isoamyl alcohol/Isobutanol.

3) $\mathrm{p}<0.05, \stackrel{* * *}{\mathrm{p}}<0.01,{ }^{* * *} \mathrm{p}<0.001,{ }^{* * * * *} \mathrm{p}<0.0001$

Table 6. Change of fusel oils in storege vessel during maturation period of Vitis coignetiae brandy

(unit: $\mathrm{mg} / \mathrm{L}$ )

\begin{tabular}{|c|c|c|c|c|c|c|c|c|c|}
\hline \multirow{2}{*}{$\begin{array}{c}\text { Maturation } \\
\text { period } \\
\text { (month) }\end{array}$} & \multicolumn{3}{|c|}{ Isobutanol } & \multicolumn{3}{|c|}{ Isoamyl alcohol } & \multicolumn{3}{|c|}{$\mathrm{a} / \mathrm{b} \mathrm{ratio}^{2)}$} \\
\hline & Oak & Stainless & Glass & Oak & Stainless & Glass & Oak & Stainless & Glass \\
\hline 0 & $\begin{array}{l}281.01 \\
\pm 0.00^{1)}\end{array}$ & $\begin{array}{c}281.01 \\
\pm 0.00\end{array}$ & $\begin{array}{c}281.01 \\
\pm 0.00\end{array}$ & $\begin{array}{l}898.33 \\
\pm 0.01\end{array}$ & $\begin{array}{c}898.33 \\
\pm 0.01\end{array}$ & $\begin{array}{c}898.33 \\
\pm 0.01\end{array}$ & $\begin{array}{c}3.20 \\
\pm 0.04\end{array}$ & $\begin{array}{c}3.20 \\
\pm 0.04\end{array}$ & $\begin{array}{c}3.20 \\
\pm 0.04\end{array}$ \\
\hline 3 & $\begin{array}{c}287.43 \\
\pm 0.01\end{array}$ & $\begin{array}{c}276.22 \\
\pm 0.01\end{array}$ & $\begin{array}{c}259.87 \\
\pm 0.01^{* * * 3)}\end{array}$ & $\begin{array}{c}905.86 \\
\pm 0.04\end{array}$ & $\begin{array}{c}873.50 \\
\pm 0.04\end{array}$ & $\begin{array}{l}822.51 \\
\pm 0.02^{* * * *}\end{array}$ & $\begin{array}{c}3.15 \\
\pm 0.02\end{array}$ & $\begin{array}{c}3.16 \\
\pm 0.03\end{array}$ & $\begin{array}{c}3.17 \\
\pm 0.06\end{array}$ \\
\hline 7 & $\begin{array}{c}314.73 \\
\pm 0.00\end{array}$ & $\begin{array}{c}269.65 \\
\pm 0.00\end{array}$ & $\begin{array}{c}270.34 \\
\pm 0.00\end{array}$ & $\begin{array}{c}1,007.16 \\
\pm 0.00\end{array}$ & $\begin{array}{c}859.49 \\
\pm 0.00\end{array}$ & $\begin{array}{l}860.04 \\
\pm 0.00^{*}\end{array}$ & $\begin{array}{c}3.20 \\
\pm 0.06\end{array}$ & $\begin{array}{c}3.19 \\
\pm 0.00\end{array}$ & $\begin{array}{c}3.18 \\
\pm 0.00\end{array}$ \\
\hline 11 & $\begin{array}{l}504.19 \\
\pm 0.06^{* * * *}\end{array}$ & $\begin{array}{c}276.74 \\
\pm 0.00\end{array}$ & $\begin{array}{c}276.86 \\
\pm 0.00\end{array}$ & $\begin{array}{l}1,642.08 \\
\pm 0.20^{* * * * *}\end{array}$ & $\begin{array}{c}876.83 \\
\pm 0.00\end{array}$ & $\begin{array}{c}876.49 \\
\pm 0.01\end{array}$ & $\begin{array}{c}3.26 \\
\pm 0.01\end{array}$ & $\begin{array}{c}3.17 \\
\pm 0.02\end{array}$ & $\begin{array}{c}3.18 \\
\pm 0.06\end{array}$ \\
\hline 17 & $\begin{array}{c}687.88 \\
\pm 0.01^{* * * * *}\end{array}$ & $\begin{array}{c}272.13 \\
\pm 0.00\end{array}$ & $\begin{array}{l}268.99 \\
\pm 0.00^{*}\end{array}$ & $\begin{array}{l}1,605.57 \\
\pm 0.01^{* * * *}\end{array}$ & $\begin{array}{c}864.75 \\
\pm 0.00\end{array}$ & $\begin{array}{c}880.74 \\
\pm 0.00\end{array}$ & $\begin{array}{c}2.33 \\
\pm 0.05\end{array}$ & $\begin{array}{c}3.18 \\
\pm 0.02\end{array}$ & $\begin{array}{c}3.27 \\
\pm 0.02\end{array}$ \\
\hline
\end{tabular}

${ }^{1)}$ Each value is expressed as mean $\pm \mathrm{SD}(\mathrm{n}=3)$.

${ }^{2)}$ Ratio = Isoamyl alcohol/Isobutanol.

3) $\mathrm{p}<0.05,{ }^{* *} \mathrm{p} 0.01,{ }^{* * *} \mathrm{p}<0.001,{ }^{* * * *} \mathrm{p}<0.0001$.

는 것을 확인하여 숙성에 따른 향기성분의 변화를 확인하였 다(Fig. 1, Table 7). 숙성된 머루 첨가 증류주의 향기성분으 로는 octanoic acid ethyl ester, hexadecanoic acid ethyl ester, decanoic acid ethyl ester, hexanoic acid ethyl ester가 주요 성분으로, 이 결과는 머루를 첨가한 약주의 주요 향기성분은 ethyl ester류임을 발표한 내용과 일치한다(Choi와 Kwak, 2012). Hexanoic acid ethyl ester, dodecanoic acid ethyl ester 는 타 지방산 에스테르류에 비해 서서히 에스테르화가 진행 되므로, 본 결과에서는 숙성기간동안 $9.30 \%$ 와, $9.32 \%$ 의 비 슷한 함량으로 생성됨을 확인하였다(Lee 등, 2001).

\section{요 약}

본 연구에서는 강원지역특화작목인 머루와 다래를 활용하 여 과실 브랜디를 제조하여 숙성용기에 숙성시킴으로써 숙성 중에 브랜디의 퓨젤유를 포함한 휘발성 향기성분 및 지방산 에스테르류의 변화를 확인하였다. 제조된 브랜디는 오크통과 스테인리스통, 유리병에 총 17 개월간 실온 숙성하였다. 숙성 17 개월 후 숙성 전에 비해 머루 브랜디와 다래 브랜디에서 숙성용기에 따른 휘발성 향기성분 중 자극성 향기성분인 아 세트알데하이드는 급격하게 감소하였고, 퓨젤유는 오크통에 
(A)

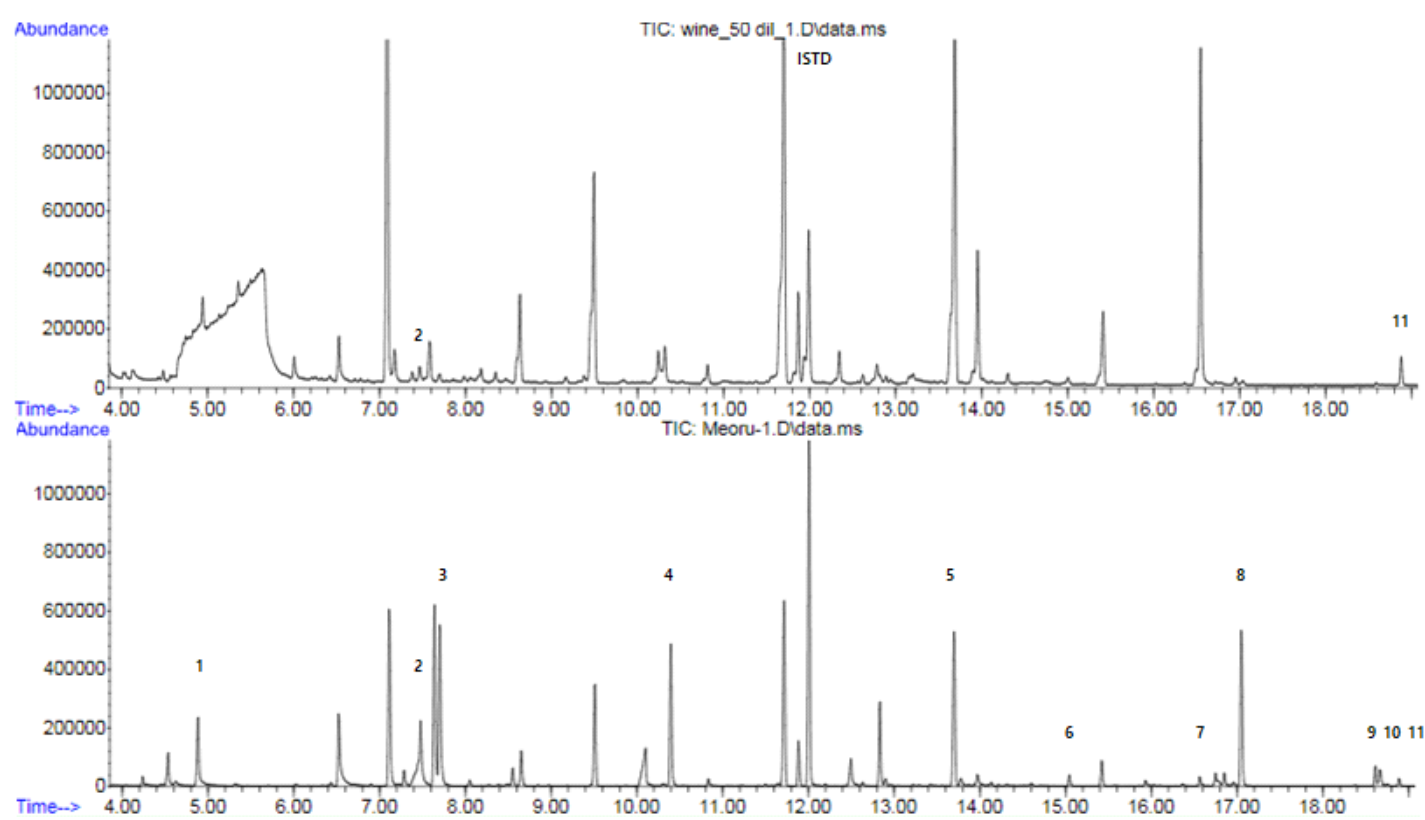

Fig. 1. Gas chromatography-mass spectrometry base peak chromatograms of (A) Vitis coignetiae wine and (B) Vitis coignetiae brandy. 1, hexanoic acid, ethyl ester; 2, butanedioic acid, diethyl ester; 3, octanoic acid, ethyl ester; 4, decanoic acid, ethyl ester; 5, dodecanoic acid, ethyl ester; 6, tetradecanoic acid, ethyl ester; 7, 9-hexadecanoic acid acid ethyl ester; 8, hexadecanoic acid, ethyl ester; 9, 9,12-octadecadienoic acid ethyl ester; 10, 6,9,12-hexadecatrienoic acid, methyl ester; 11, octadecanoic acid, ethyl ester.

ISTD, internal standard.

Table 7. Changes of fatty acid esters during maturation period of alcohol (brandy and wine) containing Vitis coignetiae

(unit: Peak area \%)

\begin{tabular}{cclccc}
\hline No & RT & \multicolumn{1}{c}{ Compounds } & $\begin{array}{c}\text { Wine } \\
\text { (initial) }\end{array}$ & $\begin{array}{c}\text { Brandy } \\
\text { (initial) }\end{array}$ & $\begin{array}{c}\text { Brandy } \\
\text { (maturation) }\end{array}$ \\
\hline 1 & 4.88 & Hexanoic acid ethyl ester & - & - & 9.30 \\
2 & 7.48 & Butanedioic acid diethyl ester & 2.14 & - & 15.03 \\
3 & 7.71 & Octanoic acid ethyl ester & - & - & 20.59 \\
4 & 10.40 & Decanoic acid ethyl ester & - & - & 16.37 \\
5 & 12.84 & Dodecanoic acid ethyl ester & - & - & 9.32 \\
6 & 15.04 & Tetradecanoic acid ethyl ester & - & - & 1.38 \\
7 & 16.85 & 9-Hexadecenoic acid ethyl ester & - & - & 2.10 \\
8 & 17.06 & Hexadecanoic acid ethyl ester & - & - & 2.43 \\
9 & 18.62 & $9,12-$ Octadecadienoic acid ethyl ester & - & - & 2.44 \\
10 & 18.67 & 6,9,12-Hexadecatrienoic acid methyl ester & - & - & 2.88 \\
11 & 18.89 & Octadecanoic acid ethyl ester & 1.80 & - & 1.16 \\
& $\quad$ Others & 96.06 & & 0 \\
\hline \multicolumn{7}{c}{ Total } \\
\hline
\end{tabular}


이는 숙성이전에 검출되지 않은 지방산 에스테르류 11종이 숙성이후에 검출됨으로 풍미에 크게 영향을 미치는 것으로 판단된다.

\section{감사의 글}

본 연구는 농촌진흥청 공동연구개발사업(과제번호: PJ01 1168 ) 지원에 의한 연구개발의 일부로 이에 감사드립니다.

\section{Conflict of interests}

The authors declare no potential conflict of interest.

\section{ORCID}

Sangmi Jung https://orcid.org/0000-0002-5662-706X

Moonjin Ra https://orcid.org/0000-0001-8148-2037

\section{References}

Choi SH, Kwak EJ. Volatile flavor compounds and sensory properties of Yakju fermented with different contents of Meoru (Vitis coignetiae). J East Asian Soc Dietary Life, 22, 642-648 (2012)

Chung H, Yoon MK, Kim MH, Park SK, Lee JG, Kim YS. Volatile hazardous compounds in alcoholic beverages. J Appl Biol Chem, 55, 141-148 (2012)

Chun MS, Kim SJ, Noa BS. Analysis of free amino acids and flavors in fermented jujube wine by HPLC and GC/MS. Korean J Food Sci Technol, 44, 779-784 (2012)

Kang SH, Kim JH, Lee AR, Kim AR, Kim TW. Physicochemical properties of rice-distilled spirit matured in oak and stainless steel containers. Korean J Food Sci Technol, 49, 369-376 (2017)

Kim JH, Lee DH, Lee SJ. Research and Development of Long Term Matured Premium Spirit through Fermentation, Distillation, and Maturation Tracking Analysis. High Value-added Food Technology Development Pro- gram funded by Ministry of Agriculture, Food and Rural Affairs (MAFRA) (11-1543000-001945-01) (2017)

Kim WK, Lee SJ. Changes in volatile compounds in ricebased distilled soju aged in different types of containers. Korean J Food Sci Technol, 51, 543-550 (2019)

Lee DH, Park IT, Lee YS, Seo JS, Jung JW, Kim TW, Kin $\mathrm{JH}$, Ahn BH. Quality characteristics of fermented wine using Nuruk by aging container and period of distilled liquor. J Korean Soc Food Sci Nutr, 43, 1579-1587 (2014)

Lee DH, Jung JW, Lee YS, Seo JS, Park IT, Kim TW, Kim $\mathrm{JH}$, Ahn BH. Quality characteristics of distilled liquor produced using Ipguk (Koji) during aging. Korean J Food Sci Technol, 46, 694-701 (2014)

Lee DS, Park HS, Kim K, Lee TS, Noh BS. Determination and multivariate analysis of flavour components in the Korean folk Sojues using GC-MS. Korean J Food Sci Technol, 26, 750-758 (1994)

Lee HK, Choi YS, Chung EH. Higher alcohols composition in Korean alcoholic beverages. Kor J Food Hygiene, 4, 257-262 (1989)

Lee KYM, Paterson A, Piggott JR, Richardson GD. Origins of flavour in whiskies and a revised flavour wheel: A review. J Inst Brew, 107, 287-313 (2001)

Lee YS, Cho EA, Cha YH, Yoon DW, Im DH, Choi BG, Jeon JH. Comparisons of flavor ingredients changes according to whisky types and maturation period. Korean J Food Nutr, 3, 471-479 (2011)

Park SG. The effect of oak on the aroma of whiskey. Korea Alcohol and Liquor Industry Association, 15, 50-59 (1995)

Peinado RA, Moreno JA, Munoz D, Medina M, Moreno J. Gas chromatographic quantification of major volatile compounds and polyols in wine by direct injection. $\mathrm{J}$ Agric Food Chem, 52, 6389-6393 (2004)

Ryu BH, Nam KD. Large scale alcohol fermentation with cassava slices at low temperature. Korean J Appl Microbiol Bioeng, 15, 75-79 (1987) 